\title{
Effect of Transfer of Symbiotic Plasmids and of Hydrogenase Genes (hup) on Symbiotic Efficiency of Rhizobium leguminosarum Strains
}

\author{
By GRETE M. SøRENSEN* AND RITA WYNDAELE \\ Department of Molecular Biology and Plant Physiology, University of Aarhus, \\ C. F. Mollers Allé 130, 8000 Aarhus C, Denmark
}

(Received 21 March 1985; revised 13 September 1985)

\begin{abstract}
Plasmid-encoded symbiotic determinants from the Rhizobium leguminosarum strain MA1 (817) with uptake hydrogenase activity $\left(\mathrm{Hup}^{+}\right.$) and from the $\mathrm{Hup}^{-}$strain $\mathrm{MCl}$ (18a) were mobilized by recombination with the self-transmissible plasmid pVW5JI. The symbiotic determinants were transferred by conjugation from strain MAl to strain $\mathrm{MCl}$ and to a derivative of $\mathrm{MCl}$ without the symbiotic plasmid, and vice versa, thus constructing four types of transconjugants. The determinants for a total recycling hydrogenase in strain MAl were found to be encoded on the symbiotic plasmid.

Strain $\mathrm{MCl}$ fixed $60 \%$ more $\mathrm{N}_{2}$ in pea root nodules, determined as mg nitrogen per plant, than strain MAl. This difference was not increased in the $\mathrm{MCl}$ derivative that obtained hydrogenase activity. Plants inoculated with a derivative of strain MA1, however, where the symbiotic plasmid was replaced by that of strain $\mathrm{MCl}$ had a high percentage nitrogen content. It was concluded that the symbiotic plasmid and the genetic background were more important for plant nitrogen accumulation than uptake hydrogenase.
\end{abstract}

\section{INTRODUCTION}

During symbiotic nitrogen fixation where $\mathrm{N}_{2}$ is reduced to $\mathrm{NH}_{4}^{+}$the enzyme system responsible, nitrogenase, also reduces protons to $\mathrm{H}_{2}$. Since the $\mathrm{H}_{2}$ production is dependent on ATP hydrolysis (Bulen \& LeComte, 1966), $\mathrm{H}_{2}$ evolved by nitrogenase represents an energy loss. Some Rhizobium strains, however, possess an uptake hydrogenase (Hup) which recycles some or all of the $\mathrm{H}_{2}$ produced by nitrogenase, whereby up to one-third of the energy lost may be regained (Schubert et al., 1978). Nitrogenase can utilize ATP produced in this way as a source of energy (Emerich et al., 1979).

Comparisons between plants inoculated with $\mathrm{Hup}^{+}$or $\mathrm{Hup}^{-}$strains have often shown that the hydrogenase-containing strains give rise to higher plant yield, expressed as $\mathrm{mg}$ nitrogen per plant (Schubert et al., 1978; Bethlenfalvay \& Phillips, 1979; Albrecht et al., 1979). A hup point mutant of $R$. japonicum produced a lower plant yield than the $\mathrm{Hup}^{+}$parent strain (Lepo et al., 1981 ), and transfer of a plasmid with Hup determinants to Hup ${ }^{-} R$. leguminosarum strains increased their $\mathrm{N}_{2}$ fixation (DeJong et al., 1982). With $R$. leguminosarum, however, a lack of correlation between Hup activity and plant yield has been observed (Ruiz-Arguëso et al., 1978; Truelsen \& Wyndaele, 1984).

Genes for nodulation and nitrogen fixation in $R$. leguminosarum seem to be located on one plasmid, the so-called symbiotic plasmid (pSym) (Krol et al., 1980; Hombrecher et al., 1981; Prakash et al., 1981). The pSym may be self-transmissible (Hirsch, 1979; Brewin et al., 1980a), or it can be mobilized by recombination with a transmissible plasmid (Brewin et al., 1980 b). It is then possible to study the effect of the pSym in interaction with various genetic backgrounds.

Abbreviation: pSym, symbiotic plasmid. 
This study concerns the mobilization and reciprocal transfer of pSyms between two $R$. leguminosarum strains, one $\mathrm{Hup}^{+}$and the other $\mathrm{Hup}^{-}$. The plasmid was transferred from one strain to the other, or to a derivative of the other without its own $\mathrm{pSym}$, and vice versa. The efficiency of one pSym as opposed to a recombination of two in the two bacterial backgrounds was investigated, comparing the amounts of fixed nitrogen in pea plants. The effect of the hydrogenase system is discussed.

\section{METHODS}

Bacteria. R. leguminosarum strains and relevant plasmids are listed in Table 1. Strains 817 and 18 a were isolated from Danish soils in our laboratory and in Research Establishment Risø, Roskilde, Denmark, respectively. Strains 2517 (carrying plasmid pVW5JI) and B151 were kindly provided by N. J. Brewin, John Innes Institute, Norwich, UK. The bacteria were grown in liquid TY medium (Beringer, 1974) or on TY agar plates with various antibiotics.

Crosses and curing of plasmids. Conjugations were done as membrane crosses as described by Beringer et al. (1978). The resulting transconjugants were checked for sensitivity to the donor-specific marker drug. Curing was done at $37^{\circ} \mathrm{C}$ in liquid TY medium for $24 \mathrm{~h}$, and single colonies from TY plates were then tested for sensitivity towards the drug to which the unwanted plasmid encoded resistance.

Plasmid analysis and DNA hybridization. Plasmids were isolated as described by Hirsch et al. (1980). Plasmid sizes were estimated from agarose gels (Casse $e$ al., 1979). Strains 2517 and B151 were used as references, and contained plasmids of the following sizes: 100, 165, 220, 250, 285 and $310 \mathrm{MDa}$ (Brewin et al., 1982). DNA homology was analysed by Southern blot hybridization according to Hombrecher et al. (1981). The $3 \cdot 5+5 \cdot 1 \mathrm{~kb}$ EcoRI digests of pGB25 carrying nif genes from $R$. leguminosarum (a generous gift from J. Hontelez, Agricultural University, Wageningen, The Netherlands), which are homologous to nif $K D H$ from Klebsiella pneumoniae, were used as hybridization probes.

Test for the presence of $p$ Syms. All $R$. leguminosarum strains containing pSyms produce a protein of unknown function, with a sub-unit size of $24 \mathrm{KDa}$ (Dibb et al., 1984). Specific antibodies against the protein (a gift from $\mathrm{N}$. $\mathrm{J}$. Brewin) made the corresponding gene a useful marker of pSyms in transconjugant strains. Bacteria were grown on slants for $6 \mathrm{~d}$, lysed and spotted onto nitrocellulose filters. The filters were incubated with the antibodies and stained as described by Dibb et al. (1984). This test enabled us to determine rapidly whether a strain contained the genetic region with symbiotic functions.

Plants. Peas (Pisum sativum L. cv. Bodil) were sown in sterilized pots and grown with $\mathrm{N}$-free nutrient solution, as described by Truelsen \& Wyndaele (1984), in a growth chamber under a light intensity of $300 \mu \mathrm{E} \mathrm{m}^{-2} \mathrm{~s}^{-1}$.

Nitrogenase and hydrogenase activities. Enzyme activities were determined using detached nodules. Plants were harvested 4 weeks after inoculation, and the nodules from three plants in one pot were pooled. Samples of 150$200 \mathrm{mg}$ fresh weight were used for each measurement. Hydrogen evolution in air and hydrogen production in $80 \%$ $\mathrm{Ar} / 20 \% \mathrm{O}_{2}(\mathrm{v} / \mathrm{v})$ were measured continuously with a Clark-type electrode as described by Truelsen \& Wyndaele (1984). Uptake hydrogenase activity was measured amperometrically on nodules cut in half to facilitate gas diffusion through the nodule tissue according to Truelsen \& Wyndaele (1984).

The amount of nitrogen fixed per plant was calculated from Kjeldahl analysis made on the plants used for nodule enzyme assays.

Reisolation of bacteria. Nodules used for enzyme assays were surface sterilized for $10 \mathrm{~s}$ in $95 \%(\mathrm{v} / \mathrm{v})$ ethanol and then $10 \mathrm{~min}$ in $0.1 \%$ acidified $\mathrm{HgCl}_{2}$, and rinsed in five changes of sterile water. The nodules were cut in half, and the plane surfaces dabbed on agar plates. The resulting colonies were tested for growth on various antibiotics and analysed for plasmid content.

\section{RESULTS}

\section{Strains $817(M A 1)$ and $18 a(M C 1)$, and their plasmid donor derivatives}

R. leguminosarum 817 and $18 \mathrm{a}$ are indigenous to Danish soils, and were chosen on the basis of their difference in Hup activity. Due to Hup activity, nodules of strain 817 do not evolve $\mathrm{H}_{2}$ even when assayed in an atmosphere of $80 \% \mathrm{Ar} / 20 \% \mathrm{O}_{2}$, where total electron flow through nitrogenase is diverted to $\mathrm{H}_{2}$ production; nodules of $18 \mathrm{a}$ have no Hup activity (Truelsen \& Wyndaele, 1984). Strain 18a had a relative efficiency [defined as $1-\left(\mathrm{H}_{2}\right.$ evolution in air/ $\mathbf{H}_{2}$ evolution in $\mathrm{Ar}: \mathrm{O}_{2}$ )] of $0 \cdot 4$, and 817 a total recycling capacity with a relative efficiency of 1.0 . Plasmid analysis of the two strains showed that their plasmid profiles were different, and provided a useful method to distinguish them. Plasmid pR1eA2 (190 MDa) from 817 and plasmid pRleC2 (210 MDa) from 18a carry nif determinants hybridizing to a nif probe from $R$. leguminosarum, and are referred to as pSyms. 
Table 1. R. leguminosarum strains and relevant plasmids

\begin{tabular}{|c|c|c|c|}
\hline Strain & $\begin{array}{c}\text { Hup } \\
\text { phenotype }\end{array}$ & Symbiotic plasmid* & $\begin{array}{c}\text { Plasmid } \\
\text { size (MDa) }\end{array}$ \\
\hline MA1 and 817 & Hup $^{+}$ & $\mathrm{pSym}(\mathrm{MA} 1)=\mathrm{pR} 1 \mathrm{eA} 2$ & 190 \\
\hline $\mathrm{MCl}$ and $18 \mathrm{a}$ & Hup $^{-}$ & $\mathrm{pSym}(\mathrm{MC1})=\mathrm{pR} 1 \mathrm{eC} 2$ & 210 \\
\hline B151 & & $\mathrm{pSym}^{-}$ & \\
\hline MA4 & Hup $^{+}$ & $\mathrm{pSym}(\mathrm{MA} 1) / \mathrm{pVW} 5 \mathrm{JI}=\mathrm{pR} \operatorname{leAd} 1$ & 310 \\
\hline MC2 & Hup - & $\mathrm{pSym}(\mathrm{MCl}) / \mathrm{pVW} 5 \mathrm{JI}=\mathrm{pRleCd} 1$ & 220 \\
\hline MA3 & & pSym(MA1) $)^{-}$ & $2 \Delta 0$ \\
\hline MC3 & & $\mathrm{pSym}(\mathrm{MC1})^{-}$ & \\
\hline MA9 $(\mathrm{MC} 2 \times \mathrm{MA} 3)$ & Hup $^{-}$ & pSym(MC1)/pVW5JI & 220 \\
\hline MA1l $($ MC2 $\times$ MA1 $)$ & Hup $^{+}$ & $\mathrm{pSym}(\mathrm{MA} 1) / \mathrm{pSym}(\mathrm{MCl}) / \mathrm{pVW} 5 \mathrm{JI}$ & 200 \\
\hline $\mathrm{MCl} 0(\mathrm{MA} 4 \times \mathrm{MCl})$ & $\mathrm{Hup}^{+}$ & pSym(MCl)/pSym(MAl)/pVW5JI & 190 \\
\hline MC13 (MA4 × MC3) & $\mathrm{Hup}^{+}$ & pSym(MAl)/pVW5JI & 205 \\
\hline
\end{tabular}

* Recombinant plasmids (e.g. pSym(MA1)/pVW5JI) are denoted by / between the plasmids from which they are derived. Plasmid pVW5JI was carried by strain 2517.

Drug-resistant derivatives of 817 and 18a, named MAl and $\mathrm{MCl}$ respectively, were obtained by spontaneous mutation. The symbiotic properties and plasmid profiles of $\mathrm{MAl}$ and $\mathrm{MCl}$ were identical to those of the wild-types, and the antibiotic markers remained stable during subculturing and nodule formation.

The self-transmissibility of the two pSyms was tested. Strain MA1 or MC1 was crossed with strain B151, which is a derivative of $128 \mathrm{C} 53$ without the pSym. The resulting mixture of the recipient and any recipients that had received a self-transmissible pSym from the donor was used to inoculate peas, but no nodules were formed.

Transfer functions were introduced into pSym(MA1) and pSym(MC1) by the plasmid pVW5JI carrying kanamycin and streptomycin resistance ( $\mathrm{Tn} 5)$ and regions with homology to pSyms (Brewin et al., 1980b). Using the procedure described by Brewin et al. (1982), donor derivatives of MA1 and $\mathrm{MC1}$, MA4 and MC2 respectively, were constructed, each containing a recombinant plasmid derived from the pSym and pVW5JI. The identity of the donor plasmids was confirmed by transfer to non-nodulating strains, plasmid analysis, hybridization to the nif probe and nodulation characteristics, which were all identical to those of the native strains.

During the strain constructions transconjugants were tested for the presence of the $24 \mathrm{KDa}$ protein. It became evident that pVW5JI was incompatible with the pSyms from strains MAI and $\mathrm{MCl}$, and so some derivatives lacking pSyms were obtained. Although these strains contained pVW5JI, this plasmid was removed from the MAl derivative by heat-curing at $37^{\circ} \mathrm{C}$, resulting in strain MA3 (non-nodulating). Attempts to cure the $\mathrm{MC1}$ derivatives of pVW5JI were not successful. Nevertheless, one of the non-nodulating derivatives, MC3, was used in a subsequent cross as $\mathrm{MCl}\left(\mathrm{pSym}^{-}\right)$.

\section{Transfer of pSyms between strains $M A 1$ and $M C 1$}

The observed incompatibility between pVW5JI and the pSyms from strains MA1 and MC1 implied that introduction of a recombinant plasmid derived from the pSym and pVW5JI would either eliminate the residing pSym (or vice versa) or create the intended recombination with this pSym.

Four crosses were made: MC2 was donor to MA1 and to MA3, and MA4 was donor to MC1 and to MC3. Selection was made for transfer of kanamycin resistance, and in the fourth cross, plants were used as secondary selection of those recipients that had obtained nodulation ability, because $\operatorname{Tn} 5$ was part of both the recipient and the transconjugants. Transconjugants were obtained of the two desired categories, those containing (i) the foreign pSym and not their own, and (ii) a recombination of their own and the foreign pSym (Table 1).

The plasmid profile (Fig. 1) of transconjugant strain MA9 shows an introduced plasmid which was identified as the donor plasmid from $\mathrm{MC2}$; the plasmid size was the same, the plasmid hybridized with the nif probe, and MA9 formed Hup- nodules on peas. 

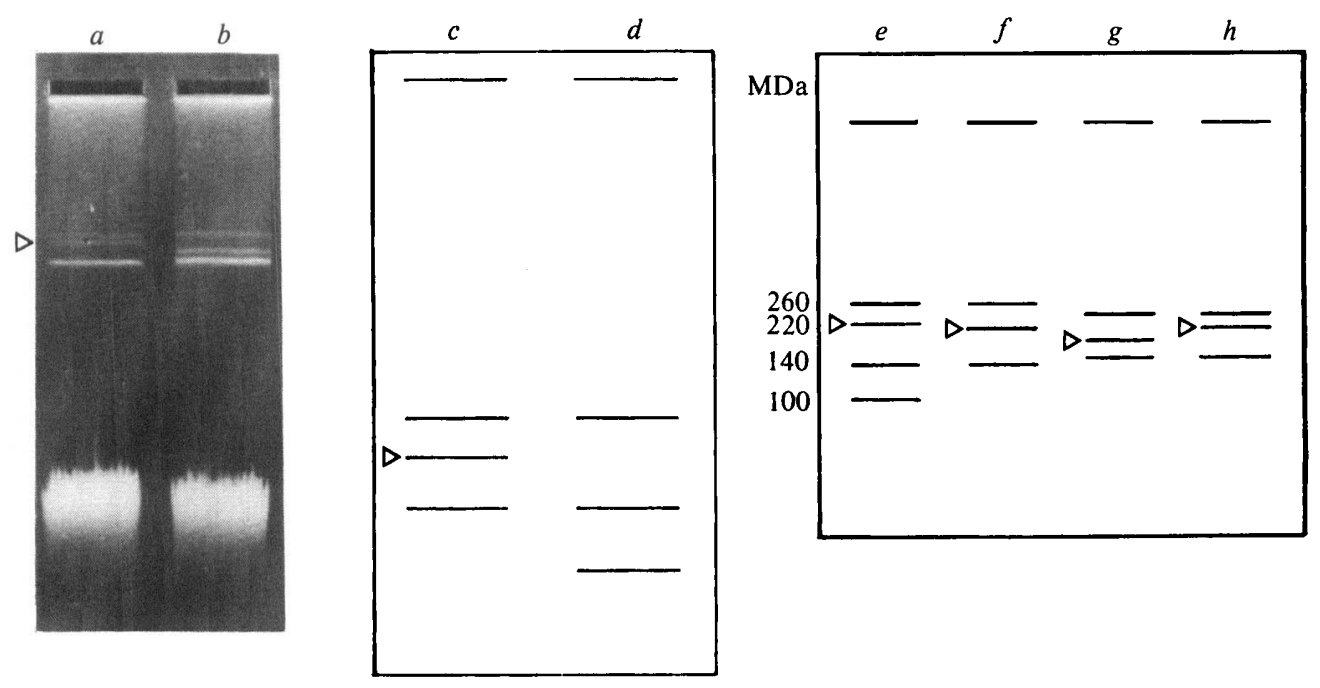

Fig. 1. Plasmid profiles of $R$. leguminosarum strains. Lane $a, \mathrm{MC} 1$, lane $b, \mathrm{MC} 3\left[\mathrm{MCl}_{(\mathrm{pSym}}{ }^{-}\right.$, pVW5JI ${ }^{+}$)], lane $c, \mathrm{MAl}$, lane $d, \mathrm{MA} 3\left[\mathrm{MAl}\left(\mathrm{pSym}^{-}, \mathrm{pRL} \mathrm{JI}^{+}\right.\right.$) (pRL7JI has no symbiotic function and co-transfers with pVW5JI; Brewin et al., 1982)], lane $e$, MA9 [MA3(pSym(MC1)/pVW5JI)], lane $f$, MAl1 [MAl(pSym(MAl)/pSym(MCl)/pVW5JI)], lane $g, \mathrm{MCl} 0[\mathrm{MCl}(\mathrm{pSym}(\mathrm{MCl}) / \mathrm{pSym}-$ (MAl)/pVW5JI)], lane $h, \mathrm{MC13}[\mathrm{MC} 3(\mathrm{pSym}(\mathrm{MAl}) / \mathrm{pVW} 5 \mathrm{JI})]$. Arrowheads indicate the bands that hybridized to the nif probe.

Strain MA11 (from the cross $\mathrm{MC} 2 \times \mathrm{MA1}$ ) was a deletion mutant of an original transconjugant, isolated because the large recombinant plasmid harboured by the transconjugant was unstable during nodule passage. The deleted plasmid then remained stable. The plasmid was interpreted as a recombination of pSym(MA1) and the donor pSym(MC1), since (i) nodules induced by MAll were Hup ${ }^{+}$, (ii) plant size and nodule mass were significantly larger after inoculation with MA11 than with MA1 (see Table 2) and (iii) MA1l was resistant to both kanamycin and streptomycin, indicating the presence of $\operatorname{Tn} 5$.

Strain $\mathrm{MC1} 3$ originated from the fourth cross and was isolated from nodules. Drug resistance and the plasmid profile (Fig. 1) showed that $\mathrm{MCl} 13$ was a derivative of $\mathrm{MCl}$, and yet the nodules had $\mathrm{H}_{2}$-uptake activity and did not evolve $\mathrm{H}_{2}$ in air or in $80 \% \mathrm{Ar} / 20 \% \mathrm{O}_{2} . \mathrm{MC} 13$ had obtained the transferable fragment $(205 \mathrm{MDa})$ of the donor plasmid from MA4, and eliminated the resident pVW5JI by incompatibility.

Strain $\mathrm{MC10}$ (from the cross $\mathrm{MA} 4 \times \mathrm{MCl}$ ) had lost pSym $(\mathrm{MCl})$ and obtained a new $190 \mathrm{MDa}$ plasmid (Fig. 1). Nodules of $\mathrm{MC10}$ had a Hup activity equal to that conferred by MAl, but nodules of $\mathrm{MCl} 10$ evolved $\mathrm{H}_{2}$ in $80 \% \mathrm{Ar} / 20 \% \mathrm{O}_{2}$ at about $25 \%$ of the evolution from nodules of $\mathrm{MCl}$. This was a strong indication that the $190 \mathrm{MDa}$ plasmid in $\mathrm{MCl} 0$ had resulted from a recombination between $\mathrm{pSym}(\mathrm{MCl})$ and the introduced donor pSym(MAl), during which a part of the donor plasmid was lost.

\section{Effect of the new strains on plant yield}

The two original and the four constructed strains were inoculated on pea plants. Nodule and plant parameters were measured 4 weeks after inoculation; the results are shown in Table 2. Nitrogenase activity (strains $\mathrm{MA} 9$ and $\mathrm{MC} 1$ ) and $\mathrm{H}_{2}$-uptake activity were the same regardless of the genetic background in which they were expressed.

Pronounced differences resulted from comparison of parameters of plant yield. The amount of fixed nitrogen per plant was $60 \%$ higher when in symbiosis with $\mathrm{Hup}^{-} \mathrm{MCl}^{-}$than with the Hup ${ }^{+}$ $\mathrm{MAl}$, as a consequence of the difference in plant mass. The plants in symbiosis with the transconjugants MA11, MC10 and MC13 were also significantly larger than those with MAl, 


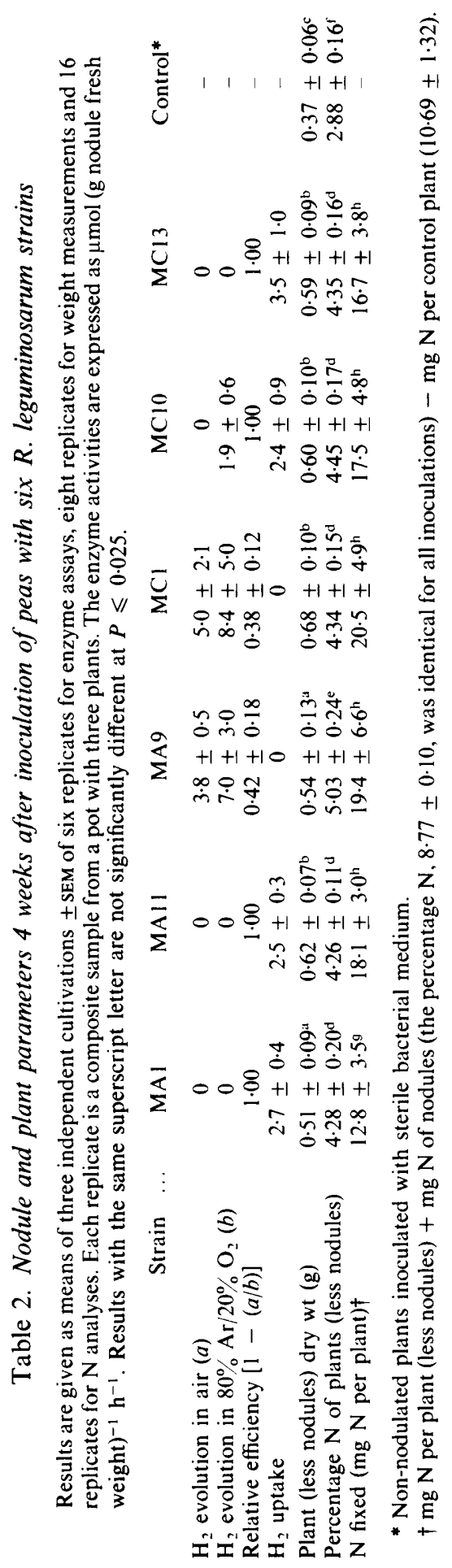


meaning that their ability to accumulate nitrogen and dry matter was greater. The plants in symbiosis with MA9 had a remarkably high percentage nitrogen content. Altogether, the differences effect a division into two groups with respect to the amount of nitrogen fixed per plant, MAl being less efficient than the rest.

\section{DISCUSSION}

The pSym of MA1 transferred into the non-nodulating strain B151 resulted in nodules with $\mathrm{H}_{2}$-uptake activity. The activity might theoretically be due to cooperation of the introduced genes and genes already present in B151, since the parent strain of B151 (128C53) was Hup ${ }^{+}$. The corresponding $\mathrm{B} 151$ derivative that contained the $\mathrm{pSym}$ of $\mathrm{MCl}$, however, induced effective, Hup ${ }^{-}$nodules, implying that the functional Hup is encoded on pSym(MA1). On the other hand, nodules of the MA1 derivative lacking its own pSym (strain MA9) did not develop Hup activity when the bacteria received nitrogenase from pSym(MC1). From this evidence it is concluded that all of the determinants needed for expression of Hup activity are carried on pSym(MA1), and are not duplicated on the rest of the MAl genome.

The difference in $\mathrm{H}_{2}$ evolution in $80 \% \mathrm{Ar} / 20 \% \mathrm{O}_{2}$ between $\mathrm{MCl} 10$ and $\mathrm{MCl} 3$ indicated that some division exists of the Hup determinants into a structural and a regulatory part, the latter being necessary for total $\mathrm{H}_{2}$ recycling. Christensen \& Schubert (1983) have reported that one recombination event between two pSyms resulted in functional genes $\left(\mathrm{Fix}^{+}\right)$, while another event conserved structural nif genes but resulted in deletion of some regulatory genes.

Provided $\mathrm{H}_{2}$ oxidation is coupled to ATP formation (Emerich et al., 1979), the possession of Hup would be expected to change the electron allocation through nitrogenase in the direction of enhanced production of $\mathrm{NH}_{4}^{+}$relative to $\mathrm{H}_{2}$ (Mortenson \& Thorneley, 1979; Wassink \& Haaker, 1984), thereby increasing the amount of fixed nitrogen per plant. The excess ATP could alternatively bring about larger plants, with the same result (Lepo et al., 1981). Nelson \& Salminen (1982), though, found coupling between $\mathrm{H}_{2}$ oxidation and ATP formation only in some of the strains examined. Another advantage of Hup has been suggested: removal of $\mathbf{H}_{2}$ from the nodule interior will decrease the extent of competitive inhibition of $\mathrm{N}_{2}$ that is caused by $\mathrm{H}_{2}$ (Hwang et al., 1973). It is an open question whether $\mathrm{H}_{2}$ diffusion through the nodule tissue is too rapid for $\mathrm{H}_{2}$ to accumulate to inhibitory levels (Dixon, 1972), or whether $\mathrm{H}_{2}$ concentrations normally reach levels above the nitrogenase $K_{i}\left(\mathrm{H}_{2}\right)$ (Dixon et al., 1981).

The two original strains, 817 and 18a, were chosen in the hope of improving plant productivity by recombining Hup function into an otherwise efficient strain. But neither MC13 nor $\mathrm{MCl} 0$ seemed to benefit from the hydrogenase when the amount of fixed nitrogen per plant was compared with that of plants in symbiosis with $\mathrm{MCl}$. In fact, none of the constructed strains gave higher nitrogen fixation than the parent $\mathrm{MCl}$, although the measured Hup activity was high enough to prevent $\mathrm{H}_{2}$ evolution in air. The main conclusion of this study is that both $\mathrm{pSym}(\mathrm{MCl})$ and the remainder of genetic material in $\mathrm{MCl}$ have properties superior to MA1. The nitrogenase activity of pSym(MC1) may be higher than of pSym(MA1), or the nitrogenase component ratio ( $\mathrm{Fe}$ protein/Mo-Fe protein) may be higher, favouring electron allocation to $\mathrm{N}_{2}$ at the expense of $\mathrm{H}^{+}$(Mortenson \& Thorneley, 1979). The influence of the genetic background may be to supply the nitrogenase system with energy and reducing power, and these traits could be more efficient in MC1. DeJong et al. (1981) also found that the nitrogen accumulation in pea plants was for some part dependent on the bacterial genetic background.

The interaction of pSym(MC1) and the background of MA1 in strain MA9 had a remarkable effect on the percentage nitrogen content of the plant, causing an increase of $17 \%$ (from $4.28 \%$ to $5.03 \%$ ) relative to MA1. Strain MA9 could be agronomically favourable in view of the pea plant as a protein source, producing a high concentration of plant protein with low fertilizer consumption.

The lack of positive effect of Hup in strains $\mathrm{MC10}$ and $\mathrm{MC1} 3$ could be for two reasons: either strain $\mathrm{MCl}$ is not adapted to utilize recycled $\mathrm{H}_{2}$ - DeJong et al. (1982) suggested that a good nitrogen-fixing strain may not have the potential to become more efficient by gaining Hup - or $\mathrm{H}_{2}$ oxidation as determined by pSym(MA1) is in fact a disadvantage. Drevon \& Salsac (1984) 
suggested that Hup may not be beneficial for nitrogen fixation in $R$. japonicum because oxidation of $\mathrm{H}_{2}$ may prevent oxidation of carbohydrates. Oxidation of $\mathrm{H}_{2}$ by $\mathrm{Hup}^{+}$nodules generates less ATP than oxidation of carbohydrates using equivalent amounts of $\mathrm{O}_{2}$. Under $\mathrm{O}_{2}$-limiting conditions the presence of Hup will lower the ATP supply available for nitrogen fixation, provided carbohydrate intake is sufficient. In nodules of pea, Dixon \& Blunden (1983) and Witty et al. (1984) have reported that nitrogenase activity was limited by $\mathrm{O}_{2}$ and not by carbohydrates, supporting the suggestion that Hup may constitute a disadvantage. The reason for the observed increase in fixed nitrogen as a consequence of $\mathrm{Hup}^{+}$plasmid transfer (DeJong et al., 1982) could, according to the results from this study, be ascribed not to hydrogenase but to the accompanying genes encoded on the transferred pSym.

$\mathrm{H}_{2}$ did not seem to build up to inhibitory levels in nodules of five of the strains listed in Table 2 , since the removal of $\mathrm{H}_{2}$ by hydrogenase gave no advantage. $\mathrm{H}_{2}$ evolution began immediately and linearly after closure of the electrode chamber, suggesting there was no diffusion barrier. Whether the symbiosis with strain MA1 does benefit from Hup because of a more open nodule structure preventing $\mathrm{O}_{2}$ limitation, or a restriction in the supply of carbohydrates from the plant, or the need to get rid of an unusually high nitrogenase-inhibiting $\mathrm{H}_{2}$ production cannot be settled without a Hup ${ }^{-}$isogenic mutant.

This work was supported by the Danish Veterinary and Agricultural Research Council (SJVF), and G. M.S. received a fellowship from the Organization for Economic Co-operation and Development (OECD). We acknowledge the skilful technical assistance of Astrid Kühle and Kirsten Sørensen, and are grateful to Dr N. J. Brewin for advice and introduction to the technique of bacterial conjugation at the John Innes Institute, Norwich, UK. We also thank Dr B. U. Jochimsen for experimental advice.

\section{REFERENCES}

Albrecht, S. L., Maier, R. J., Hanus, F. J., Russell, S. A., Emerich, D. W. \& Evans, H. J. (1979). Hydrogenase in Rhizobium japonicum increases nitrogen fixation by nodulated soybeans. Science 203, $1255-1257$.

BERINGER, J. E. (1974). R factor transfer in Rhizobium leguminosarum. Journal of General Microbiology 84, 188-198.

Beringer, J. E., Hoggan, S. A. \& Johnston, A. W. B. (1978). Linkage mapping in Rhizobium leguminosarum by means of $\mathbf{R}$ plasmid-mediated recombination. Journal of General Microbiology 104, 201-207.

Bethlenfalvay, G. J. \& Phillips, D. A. (1977). Effect of light intensity on efficiency of carbon dioxide and nitrogen reduction in Pisum sativum. Plant Physio$\log y$ 60, 868-871

Bethlenfalvay, G. J. \& Phillips, D. A. (1979). Variation in nitrogenase and hydrogenase activity of Alaska pea root nodules. Plant Physiology 63, 816820.

Brewin, N. J., Beringer, J. E. \& Johnston, A. W. B. $(1980 a)$. Plasmid-mediated transfer of host-range specificity between two strains of Rhizobiumleguminosarum. Journal of General Microbiology 120, 413420.

Brewin, N. J., DeJong, T. M., Phillips, D. A. \& Johnston, A. W. B. (1980b). Co-transfer of determinants for hydrogenase activity and nodulation ability in Rhizobium leguminosarum. Nature, London 288 , 77-79.

Brewin, N. J., WoOd, E. A., Johnston, A. W. B., DibB, N. J. \& Hombrecher, G. (1982). Recombinant nodulation plasmids in Rhizobium leguminosarum. Journal of General Microbiology 128, 18171827.
Bulen, W. A. \& LeComte, J. R. (1966). The nitrogenase system from Azotobacter: two-enzyme requirement for $\mathrm{N}_{2}$ reduction, ATP-dependent $\mathrm{H}_{2}$ evolution, and ATP hydrolysis. Proceedings of the National Academy of Sciences of the United States of America 56, 979-986.

Casse, F., Boucher, C., Julliot, J. S., Michel, M. \& DÉNARIÉ, J. (1979). Identification and characterization of large plasmids in Rhizobium meliloti using agarose gel electrophoresis. Journal of General Microbiology 113, 229-242.

Christensen, A. H. \& Schubert, K. R. (1983). Identification of a Rhizobium trifolii plasmid coding for nitrogen fixation and nodulation genes and its interaction with pJB5JI, a Rhizobium leguminosarum plasmid. Journal of Bacteriology 156, 592-599.

DeJong, T. M., Brewin, N. J. \& Phillips, D. A. (1981). Effects of plasmid content in Rhizobium leguminosarum on pea nodule activity and plant growth. Journal of General Microbiology 124, 1-7.

DeJong, T. M., Brewin, N. J., Johnston, A. W. B. \& PhILlips, D. A. (1982). Improvement of symbiotic properties in Rhizobium leguminosarum by plasmid transfer. Journal of General Microbiology 128, 18291838.

DibB, N. J., Downie, J. A. \& Brewin, N. J. (1984). Identification of a rhizosphere protein encoded by the symbiotic plasmid of Rhizobium leguminosarum. Journal of Bacteriology 158, 621-627.

Dixon, R. O. D. (1972). Hydrogenase in legume root nodule bacteroids: occurrence and properties. $\mathrm{Ar}$ chives of Microbiology 85, 193-201.

Dixon, R. O. D. \& Blunden, E. A. G. (1983). The relative efficiency of nitrogen fixation in pea root nodules. Plant and Soil 75, 131-138. 
Dixon, R. O. D., Blunden, E. A. G. \& Searl, J. W. (1981). Intercellular space and hydrogen diffusion in pea and lupin root nodules. Plant Science Letters 23, $109-116$.

Drevon, J.-J. \& SALSAC, L. (1984). Is hydrogenase activity beneficial for nitrogen fixation by soybean root nodules? In Advances in Nitrogen Fixation Research, p. 499. Edited by C. Veeger \& W. E. Newton. The Hague: M. Nijhoff/Dr W. Junk Publishers/Pudoc.

Emerich, D. W., Ruiz-Argüeso, T., Ching, T. M. \& Evans, H. J. (1979). Hydrogen-dependent nitrogenase activity and ATP formation in Rhizobium japonicum bacteroids. Journal of Bacteriology 137, 153-160.

HIRSCH, P. R. (1979). Plasmid-determined bacteriocin production by Rhizobium leguminosarum. Journal of General Microbiology 113, 219-228.

Hirsch, P. R., van Montagu, M., Johnston, A. W. B., Brewin, N. J. \& Schell, J. (1980). Physical identification of bacteriocinogenic, nodulation and other plasmids in strains of Rhizobium leguminosarum. Journal of General Microbiology 120 , 403-412.

HOMbrecher, G., Brewin, N. J. \& Johnston, A. W. B. (1981). Linkage of genes for nitrogenase and nodulation ability on plasmids in Rhizobium leguminosarum and R. phaseoli. Molecular and General Genetics 182, 133-136.

Hwang, J. C., Chen, C. H. \& Burris, R. H. (1973). Inhibition of nitrogenase-catalysed reductions. Biochimica et biophysica acta 292, 256-270.

Krol, A. J. M., Hontelez, J. G. J., Van den Bos, R. C. \& VAN Kammen, A. (1980). Expression of large plasmids in the endosymbiotic form of Rhizobium leguminosarum. Nucleic Acids Research 8, 4337-4347.

LePo, J. E., Hickok, R. E., Cantrell, M. A., Russell, S. A. \& Evans, H. J. (1981). Revertible hydrogen uptake-deficient mutants of Rhizobium japonicum. Journal of Bacteriology 146, 614-620.

Mortenson, L. E. \& Thorneley, R. N. F. (1979). Structure and function of hydrogenase. In Annual Review of Biochemistry, vol. 48, pp. 387-418. Edited by E. E. Snell. Palo Alto: Annual Reviews Inc.

Nelson, L. M. \& Salminen, S. O. (1982). Uptake hydrogenase activity and ATP formation in Rhizobium leguminosarum bacteroids. Journal of Bacteriology 151, 989-995.

Prakash, R. K., Schilperoort, R. A. \& Nuti, M. P. (1981). Large plasmids of fast-growing rhizobia: homology studies and location of structural nitrogen fixation (nif) genes. Journal of Bacteriology 145, 1129-1136.

Ruiz-Argüeso, T., Hanus, J. \& Evans, J. H. (1978). Hydrogen production and uptake by pea nodules as affected by strains of Rhizobium leguminosarum. Archives of Microbiology 116, 113-118.

Schubert, K. R., Jennings, N. T. \& Evans, H. J. (1978). Hydrogen reactions of nodulated leguminous plants. II. Effects on dry matter accumulation and nitrogen fixation. Plant Physiology 61, 398-401.

TRUelsen, T. A. \& Wyndaele, R. (1984). Recycling efficiency in hydrogenase uptake positive strains of Rhizobium leguminosarum. Physiologia plantarum 62 , 45-50.

WASSINK, H. \& HAAKER, H. (1984). Electron allocation to $\mathrm{H}^{+}$and $\mathrm{N}_{2}$ by nitrogenase of Rhizobium leguminosarum bacteroids. In Advances in Nitrogen Fixation Research, p. 167. Edited by C. Veeger \& W. E. Newton. The Hague: M. Nijhoff/Dr W. Junk Publishers/Pudoc.

WitTy, J. F., Minchin, F. R., SheEhy, J. E. \& INES Minguez, M. (1984). Acetylene-induced changes in the oxygen diffusion resistance and nitrogenase activity of legume root nodules. Annals of Botany 53, 13-20. 